\title{
Li Pittori Parlano con l'Opere: Visualizing Poetry in Practice in Early Modern Italian Art
}

\author{
By James Hutson*
}

\begin{abstract}
The relative sophistication of artists in the early modern era is contested, especially with regards to their educational backgrounds. On one hand, Dempsey-esque intellectual history is vested in touting the structured, literary curricula in art-educational institutions; while on the other, a complete rejection of the "artist-philosopher" as historical fiction seeks to undermine this hegemonic construct. This study argues that the lack of early formal education in the cases of artist like Annibale Carracci and Nicolas Poussin, who, unlike Peter Paul Rubens, did not have a firm foundation in the classics and languages that would allow them to engage directly with source material, would later be supplemented through their relationships with literary figures in the circles of Torquato Tasso, Giambattista Marino, and the Accademia dei Gelati. In addition to such relationships, informal exchanges, gatherings, and supplemental materials like Giovanni Paolo Gallucci's Della Simmetria could be called upon when treating poetic subjects. With intimate knowledge of vernacular poetry, literati themselves participating in lectures and studio visits, and, finally, quick reference guides for subject matter, these artists were able to produce works that spoke to both poetic and artistic theory of the day, as one naturally informed the other.
\end{abstract}

\section{Introduction}

"Poets paint with words, painters speak with their works." ${ }^{1}$ This aphorism of Annibale Carracci (1560-1609) followed a superb rendering of the Laocoön in charcoal, expertly rendered from memory. The virtuoso display and acerbic quip was aimed at his brother Agostino Carracci (1557-1602), who had rebuked his failure to engage in a discussion on ancient statuary. ${ }^{2}$ In the anecdote here, recorded by the academic biographer Giovan Pietro Bellori (1613-1696), we find a theme that runs throughout his Lives: artists can base their styles on theory or

"Professor, Lindenwood University, USA.

Sections of this paper were presented as "Li pittori parlano con l'opere: Poetry and Practice in the Academic Tradition," College Art Association (Washington, D.C., 2016). Unless otherwise indicated, all translations are the author's.

1. Giovan Pietro Bellori, Le Vite de Pittori, Scultori e Architetti Moderni (Rome, 1672), (eds.) Evelina Borea and Giovanni Previtali (Turin: Einaudi, 1976), 31; Bellori, The Lives of the Modern Painters, Sculptors and Architects, (trans.) Wohl and Wohl (Cambridge: Cambridge University Press, 2005), 77.

2. Bellori, Le Vite de Pittori, Scultori e Architetti Moderni, 31. 
practice, while a tempering of one with the other is ideal. ${ }^{3}$ The learned, academic artist is held up as a model to be emulated in institutions like the Accademia di San Luca, where Bellori would deliver his lecture that would serve as the theoretical basis for evaluating artists in the seventeenth-century and beyond. ${ }^{4}$ Recent scholarship, however, has demonstrated that, outside of Florence, formal academies were not the primary means by which artists gained an education. ${ }^{5}$ Instead, they provided supplemental training, shoring up deficiencies that persisted after traditional apprenticeships. While the Roman, Bolognese and French academies struggled to find their place in the changing artistic landscape of early modernity, artists bolstered their new image as intellectuals through associations with a variety of literary and scholarly personalities. The relationships not only assisted in the development of poetic concetti and subjects for istorie, they also introduced to artists new circles through which to develop contacts and receive patronage. But exactly what was the nature of this exchange, and how well were artists prepared to engage with their so-called "sister" discipline?

The relative sophistication of artists in the early modern era is contested, especially with regards to their educational backgrounds. On one hand, Dempsey-esque intellectual history is vested in touting the structured, literary curricula in art-educational institutions; while on the other, a complete rejection of the "painter-philosopher" trope as historical fiction seeks to undermine this hegemonic construct. ${ }^{6}$ After all, Carlo Cesare Malvasia (1616-1693) recorded that the grammar school education of Annibale and Agostino Carracci was cut short.

3. The foil for Annibale can be found in Caravaggio's biography where Bellori admonishes the artist for his reliance on nature without considering the Idea to purify corrupted form. Bellori, 201-216.

4. Bellori, "Idea della Bellezza," Le Vite de Pittori, Scultori e Architetti Moderni, 3-13.

5. See Peter Lukehart (Ed.), The Accademia Seminars: The Accademia di San Luca in Rome, c.1590-1635. CASAVA Seminar Papers 2 (New Haven, London: National Gallery of Art - Studies in the History of Art, 2009); Peter Lukehart, "The 'Accademia dei Scultori' in Late Sixteenth- and Seventeenth-Century Rome," in Anthony Colantuono and Steven F. Ostrow (eds.), Critical Perspectives on Roman Baroque Sculpture (University Park, Pennsylvania : The Pennsylvania State University Press, 2014), 17-23; Marianne Pade, On Renaissance Academies: Proceedings of the International Conference "From the Roman Academy to the Danish Academy in Rome -Dall'Accademia Romana all'Accademia di Danimarca a Roma": The Danish Academy in Rome, 11-13 October 2006 (Roma, 2011), 34-51; Carl Goldstein, Teaching Art: Academies and Schools from Vasari to Albers (New York, 1996); Anne Sutherland Harris, "Annibale's Legacy: Proposals for Giovanni Angelo Canini and Antonio Carracci," Master Drawings 43, no. 4 (2005), 453; Patrizia Cavazzini, Painting as Business in Early Seventeenth-Century Rome (University Park, Pennsylvania, 2008).

6. See Charles Dempsey, "Some Observations on the Education of Artists in Sixteenth-Century Florence and Bologna," Art Bulletin 62 (1980): 552-569; Carl Goldstein, Visual Fact over Verbal Fiction: A Study of the Carracci and the Criticism, Theory and Practice of Art in Renaissance and Baroque Italy (Cambridge, New York: Cambridge University Press, 1988). 
Their cousin Ludovico Carracci (1555-1619), we are told, had them withdrawn to pursue painting when they "spent all their time covering the margins of their books and the walls outside with scribbled drawings" rather than engaging with the material. ${ }^{7}$ Even Bellori admits to the humble beginnings of the brothers, who were raised by their father, a tailor, "respectably in his poverty." ${ }^{8}$ At the end of his biographies, reflecting that of Annibale, Bellori notes how even though Nicolas Poussin's (1594-1665) father had him study letters, the boy also chose instead to "decorate books and the school with his drawings." 9 The anecdotes scarcely foretell the academic ideal these artists would come to embody.

These anecdotes call into question the literary sophistication of the artists under discussion. Is then the narrative woven by Bellori and later biographers mere fiction in their attempt to trace the classical tradition directly from Raphael (1483-1520) to his inheritors in the Carracci and, finally, Poussin? How can we reconcile the arguments that literati were merely justifying their taste with an anachronistic theory after the fact; exactly how were these Carraccesque artists engaging with poets and poetic theory, and, lastly, how did they apply it to the art-theoretical trends of their day? This paper will argue that the lack of early formal education in the cases of Annibale and Poussin did not provide them with a firm foundation in the classics and languages. This deficiency, however, would later be supplemented through their relationships with literary figures in the circles of Torquato Tasso (1544-1595) and Giambattista Marino (1569-1625). In addition to such relationships, informal exchanges and gatherings, as well as supplemental materials could be referenced when treating poetic subjects, such as Giovanni Paolo Gallucci's (1538-1621) physiognomic guide for artists. ${ }^{10}$ With intimate knowledge of vernacular poetry, literati themselves participating in lectures and studio visits, and, finally, with quick reference guides for subject matter, these artists were able to produce works that spoke to both poetic and artistic theory of the day, as one naturally informed the other.

\section{Grammar Education and Artists}

Central to the argument of the use of literary sources by artists are the academies founded to further their education. The perception and framing of artists and their academies in the early modern era has paralleled the rise of related studies, as well as the shifting critical relationship of the period to those

7. Anne Summerscale (Ed.) Malvasia's Life of the Carracci (University Park, Pennsylvania: Pennsylvania State University Press, 2000), 86.

8. Bellori, The Lives of the Modern Painters, Sculptors and Architects, 72.

9. Bellori, 309.

10. Giovanni Paolo Gallucci, Della Simmetria dei Corpi Humani, Libri Quattro (Venice, 1591) (Reprinted, Venice: Roberto Meietti, 1594). 
before and after. Early studies devoted to the era in question tended to frame it antithetically to the preceding: the style of the late sixteenth century was erudite, literary-minded and artificial; thus the new 'anti-mannerist' style was grounded in life study, turning back to the practical matters of the workshop (bottegha). Such was the estimation of Walter Friedlaender where he noted that it was the reliance on purely theoretical concepts that gave rise to the phenomenon of "Mannerism," which was practiced by the more literary-minded artists of the late-sixteenth century, such as Federico Zuccaro (1542-1609). Consequently, the originators of the anti-mannerist style, Annibale Carracci and Caravaggio (1571-1610), lacked a theoretical side: "They did not theorize nearly as much as the maniera people..."11 This position would be reversed in the 1970s and 80s as the developments of the era were seen to have formed the groundwork for the academic tradition that would fully crystallize in the French Academy with a rigorous curriculum that demanded equal mastery of craft and the theoretical principles underpinning the visual arts. ${ }^{12}$ More recent studies have sought a more nuanced understanding of the artist's education, considering not solely theory or practice, but individual experiences without period generalization. ${ }^{13}$

Practitioners of the visual arts, both in the workshop and academy, needed a working knowledge of the subject matter and themes they would be called upon to create. In order to engage with the source material, suitable language skills were required for the profession throughout the period. How artists gained these skills and the depth of their knowledge- both in languages and literary worksvaried greatly. As such, we are unable to speak of a typical educational track for artists, but through numerous case studies we are able to assess the general level of education the average artist received. Dempsey noted in his treatment of the early training and education of artists of the period that many completed at least the fundamentals of grammar school prior their apprenticeships with a master. ${ }^{14}$ These aspiring artists would then enter the profession able to at minimum read and write in the vernacular and, in some cases, Latin. Upon the completion of apprenticeship, young artists could continue their education in art academies, such as those in Bologna and Rome, which would provide additional training in the fundamentals of grammar and rhetoric to prepare them for discourse on

11. Walter Friedlaender, Mannerism and Anti-Mannerism in Italian Painting (New York, 1965), 53.

12. Nikolaus Pevsner, Academies of Art, Past and Present (New York: De Capo Press, 1973); Dempsey, "Some Observations on the Education of Artists in Sixteenth-Century Florence and Bologna," 552-569.

13. Lukehart (Ed.), The Accademia Seminars: The Accademia di San Luca in Rome, c.1590-1635; Colantuono and Ostrow (Eds.), Critical Perspectives on Roman Baroque Sculpture; Pade, On Renaissance Academies; Goldstein, Teaching Art: Academies and Schools from Vasari to Albers.

14. Dempsey, "Some Observations on the Education of Artists in Sixteenth-Century Florence and Bologna," 552-569. 
theoretical inquiries, as well as the more practical aspects of the profession. However, the level of literary and theoretical understanding differed markedly by artist given their individual circumstances. As noted, Malvasia relates how Annibale and Agostino were sketching in the margins of their grammar texts instead of seriously participating in lessons (the trope was standard in artists' biographies since Giorgio Vasari (1511-1574) and foretold their natural inclinations towards the visual arts). ${ }^{15}$ Taking note, Ludovico petitioned to have them withdrawn to pursue their careers as painters. At that point, Annibale, Malvasia suggests, had only learned the fundamentals of reading and writing in Latin. ${ }^{16}$ Colantuono related a similar trend with their pupils: Guido Reni (1575-1642), for instance, briefly studied unsuccessfully at the scuola di grammatica. ${ }^{17}$ By this time, the scope of education had expanded. It is important to note that by 1587 , the goals of Latin teachers in the scuola included both Latin grammar and ancient literature, thus the terms became interchangeable with "grammatica."18 Therefore, students would be familiarized with the classics, as well as how to read them.

Individuals who attended such schools were not originally intending to be artists. Many of the artists who attended Latin school did so in hopes of pursuing lucrative careers in letters, law or even in the clergy. In many instances, their talents and/or desire to become artists often interfered with their schooling, and thus the length of their attendance at school, and their consequent level of proficiency in Latin were variable. Grendler confirms this when he differentiates the goals of the Latin school from that of the vernacular: the former prepared students to go on to university and careers in civil service, while the latter covered professional skills, such as reading, writing, use of the abbaco, and bookkeeping. ${ }^{19}$ Interestingly, the visual arts were a unique profession that benefitted from both; engagement with advanced literary subjects was a prerequisite to their success, and they were business owners that also had to manage workshops, correspond with clients, and keep account ledgers. Yet, how much these future artists learned during their often brief time at grammar school is open to debate. Though Agostino had an excellent grasp of Latin and a mastery of eloquent prose himself, Annibale resisted the classification as a necessity for artists. Regardless, the importance of having a literary education was well-

15. Summerscale (Ed.), Malvasia's Life of the Carracci, 86.

16. An understanding of the vernacular would have been taught at home by their parents. Summerscale (Ed.), 88.

17. Anthony Colantuono, Guido Reni's Abduction of Helen: The Politics and Rhetoric of Painting in Seventeenth-Century Europe (Cambridge: Cambridge University Press, 1997), 11.

18. Grendler notes that some teachers used the terms as such: $i$ fondamenti dell'humanità o della grammatica. Paul Grendler, Schooling in Renaissance Italy: Literacy and Learning, 1300-1600 (Baltimore: Johns Hopkins University Press, 1989), 47.

19. Grendler, 409. 
established prior to these artists. Vasari, for instance, relates the growing importance of Latin for artists in many of his artist biographies. ${ }^{20}$

\section{Art and Literary Academies}

Though precisely how proficient these artists had become before leaving the grammatica is open to debate, that the experience would be seminal to the curriculum created to shore up such deficiencies is evident. Established in 1582 upon Annibale and Agostino's return from studying in Venice and Rome, the Accademia degli Incamminati differed markedly from that found in the comparatively stable Florentine Duchy. Certainly the advances made by the Florentine Accademia del Disegno in systematizing art education helped shape this new curriculum taught by the Carracci. ${ }^{21}$ However, without the stability provided through state support, the experiences of the brothers were shared by many who would come to study there. Feigenbaum relates that many arrived not as youth without apprenticeships or training under other masters, but instead as adults, often with substantial training. We can point to several examples that came to the Carracci at an age where they should have already set up their own studio as a master, such as Lucio Massari (1569-1633) who was twenty-four, Pietro Faccini (1562-1602) was twenty-six, and both Francesco Albani (1578-1660) and Guido Reni were in their late teens. Therefore, Feigenbaum notes, artists were commonly twenty or older when they arrived to study where previously others of the same age would have been practicing as journeymen or setting up their own studios. ${ }^{22}$ The situation is confirmed in drawings of activities in the academy where we see students of various ages sketching alongside one another, while the masters paint on easels nearby. ${ }^{23}$ Thus, the sequence of study at the academy, outlined in Agostino's funeral oration, was purposely flexible, while still providing the tripartite division similar to that seen in Florence. This began with extensive training in life drawing, followed by an introduction to mathematical principles, and, ultimately, the narratives that would identify specific subjects to include in a particular istoria. ${ }^{24}$ Understanding the

20. Giorgio Vasari, Le Vite de' più Eccellenti Pittori Scultori e Architettori: Nelle Redazioni del 1550 e 1568. (ed.) Paola Barocchi (Firenze : Sansoni, 1966), 4: 179; 4: 290; 5: 443; 6: 143; 6: 322.

21. Karen Edis-Barzman, The Florentine Academy and the Early Modern State: The Discipline of Disegno (Cambridge: Cambridge University Press, 2000).

22. Feigenbaum, "Practice in the Carracci Academy," in Lukehart (ed.), The Accademia Seminars, 89.

23. See School of the Carracci (Attributed), Artists Drawing a Clothed Male Model (c. 1590), Red chalk on paper. Ecole des Beaux-Arts, Paris.

24Summerscale (Ed.), Malvasia's Life of the Carracci, 212. 
interdisciplinary needs of their pupils, regular drawing lessons and competitions were accompanied by discussions and guest lectures on literature and theory. Feigenbaum singles out Lanzoni, who demonstrated anatomical dissections, as well as other artists who were brought in twice-monthly to judge drawing competitions. Ulisse Aldrovandi, the Bolognese naturalist, frequented the pupils' studios, as did the humanist Achille Bocchi. ${ }^{25}$ Participants were drawn from a variety of organizations revolving around the University of Bologna: anatomists, humanists, naturalists, and, significantly, scholars and poets would alternately offer instruction and engage with both pupils of the Carracci and other established artists in attendance.

Therefore, an interdisciplinary approach helped define the Bolognese academy. The variety of disciplines called upon to supplement instruction at the Carracci Academy attest to the importance given to training beyond the workshop, and even visual arts themselves. In fact, even more influential than other artistic academies in the area, Robertson notes, were a number of literary ones, such as the Accademia dei Gelati, of which Agostino was a member. ${ }^{26}$ It should be remembered that the riposte from Annibale recorded by Bellori was wounding "in more ways than one, for he composed verses and prided himself greatly on the title of poet." 27 Established in 1588 by Melchiorre Zoppio (ca.15441634), the Gelati were dedicated at the outset to poetry and synthesizing a new literary manner. ${ }^{28}$ This so-called 'Seicentismo' sought to create novel lyrical conceits from the late style of Tasso. ${ }^{29}$ Their precedings would have been of great interest to Agostino and the Carracci, but their involvement in such an organization was not unique; likewise, the perceived importance of associating with poets was not a new dictum. Since the fifteenth century, and initial endeavors to have the visual arts included among the liberal, artists were required to befriend scholars and poets. Leon Battista Alberti (1404-1472) had recommended in his Della Pittura of 1435 that: "the studious painter to make himself familiar with poets, orators and other men of letters, for he will not only obtain excellent ornaments from such learned minds, but he will also be assisted in those very inventions which in painting may gain him the greatest possible praise." 30 The solution was no less valid a century and a half later. Yet, the relationship between poetry and the visual arts for the Carracci would go beyond merely bolstering their reputations; a central tenet of the curriculum was how poetic theory could assist in the construction of conceits (concetti), or rhetorical

25. Feigenbaum, "Practice in the Carracci Academy," 91-92.

26. Clare Robertson, The Invention of Annibale Carracci (Silvana, 2008), 73.

27. Bellori, The Lives of the Modern Painters, Sculptors and Architects, (trans.) Wohl, 77.

28. See The Database of Italian Academies.

29. Colantuono, Guido Reni's Abduction of Helen, 10.

30. Cecil Grayson (Ed.), Leon Battista Alberti on Painting and Sculpture: The Latin Texts of 'De Pictura' and 'De Statua' (London: Phaidon Press, 1972), 97. 
devices in structuring works of art. Given that the goal of painting is one of persuasion like oration, both used rhetoric, such as enthymematic arguments. The course of study would then center on the development and refinement of conceits as in literature, and other poetic devices that were now given visual form. The concetto would serve as an ornament to the primary subject, embellishing or enlivening it through clever iconographic additions or juxtapositions. ${ }^{31}$ The process of giving visual form to these framing devices paralleled, but also drew heavily from literature and poetry; often the very subjects on which these invenzione would be appended were derived from the same source that also provided the theoretical tool to select ideal subjects. ${ }^{32}$ In the case of the Carracci and their followers, the method and subject can be found in the highly acclaimed epic poet Torquato Tasso in his Gerusalemme liberata of 1581 and Discorsi dell'arte poetica of 1587 and the highly influential Discorsi del poemo eroico a year before his death in 1594. Through the circle of the Gelati, Tassian literary themes and strategies for the imitation of ideal models would become synonymous with Carraccismo. As Colantuono has argued, in the second half of the seventeenth century, the manner of the Carracci came to be seen as analogous to the poetics of Tasso's Gerusalemme. ${ }^{33}$ Since the Carracci pioneered the portrayal of his literary themes, and the idealized, Zeuxinian method that came to be associated with Carraccesque painting was seen as illustrative of the Tassian epic literary style, later treatments would elide the two as artists would turn to the Carracci precedents for both subject and style.

\section{Poetic Theory and the Arts}

The artists who matriculated in the Carracci Academy would prove to have internalized the literary precepts in their lessons. In his treatment of the pictorial stylistics of the Carracci followers, Colantuono clarifies this relationship, noting that not only were the artists the first to illustrate scenes from Tasso's epic, they adopted the Zeuxinian practice demanded by the poet in his theoretical writings. ${ }^{34}$ Malvasia, for instance, relates that when visiting the studio of Albani,

31. Poussin would later define concetto as comprising one of four elements of pictorial maniera magnifica, Colantuono relates. Anthony Colantuono, "Lorenzo Lippi, Torquato Tasso and Seventeenth-Century Pictorial Stylistics," in M. Rossi and F. Gioffredi Superbi (eds.), L'Arme e gli Amori. Ariosto, Tasso and Guarini in Late Renaissance Florence II (Firenze: Olschki, 2004), 402; Bellori, Le Vite, 478-481.

32. Giovanna Perini, "Ut Pictura Poesis: l'Accademia dei Gelati e le Arti Figurative," in D. S. Chambers and Francois Quiviger (eds.), Italian Academies of the Sixteenth Century. (London: The Warburg Institute 1995), 113-126.

33. Colantuono, "Lorenzo Lippi," 415.

34. Colantuono, Guido Reni's Abduction of Helen, 10. 
the artist had worn out copies of Tasso that those present would read aloud to him, imprinting the stories from the First Crusade, as "noble ideas on his mind." ${ }^{35}$ More specifically, Malvasia relates how different conceits could be applied to painting: "Speculating and reflecting on these passages, he knew how to extract from them thoughts, never before imagined by anyone else, which, no less than delighting, instructed even the most learned among us." 36 The practice was certainly derived from their exposure to the Carracci Academy, whose members knew the poem by heart. Both Bellori and Malvasia, for instance, relate Annibale's intimate knowledge of the epic in an anecdote when standing before Romano's Battle of Constantine, for he "burst out and began to recite the first lines of Tasso, 'I sing of pious arms and the captain,' and finding the description of this battle, he demonstrated that painting had its own poem and hero'." ${ }^{37}$ The same biographers confirm that Agostino would be the first to illustrate the epic with nine engravings, while Annibale would follow the poet's descriptions in his many mythological works and when designing the Farnese Gallery. ${ }^{38}$ Following their example, several in the Carracci circle would also illustrate individual scenes based on the epic, including: Ludovico, Domenichino, Guercino, Lanfranco, Albani, Agostino, and, finally, Poussin. Robertson, Colantuono, Unglaub, and others have recently investigated what scenes and in what manner each were treated, which I will not recite here. ${ }^{39}$ Suffice it to say, the overwhelming preference of these artists was, unexpectedly, not to illustrate the epic battle scenes from the First Crusade. Instead almost all chose lyrical interludes celebrating the tribulations of love centering on the characters of Erminia, Armida and Rinaldo. Such scenes illustrate not only the preference for lyrical subject matter, but also how their adornment was indebted to the poetics of Tasso. ${ }^{40}$ Domenichino (1581-1641), for instance, includes many concetti in several works to embellish Tasso's narratives, such as the Rinaldo and Armida of around 1620. Along with the principle subjects, Domenichino includes his own inventions such as the Cupid, kissing doves, and a sleeping Cupid. Each element, Colantuono notes, comments on the narrative unfolding as the Christian knight is bewitched, but foreshadows the reversal in fortune for Armida as she will, in turn, fall in love. ${ }^{41}$ As well, Annibale's Rinaldo and Armida, painted around 1601 for Odoardo

35. Carlo Cesare Malvasia, Felsina Pittrice (ed.) Adriana Arfelli (Bologna, 1961), 2: 234, 254.

36. Malvasia, Felsina Pittrice, 156.

37. Summerscale (Ed.), Malvasia's Life of the Carracci, 286; Bellori, The Lives of the Modern Painters, Sculptors and Architects (trans.) Wohl, 96-97.

38. Summerscale (Ed.), 164; Bellori, 123.

39. Robertson, The Invention of Annibale Carracci; Colantuono, Guido Reni's Abduction of Helen; Jonathan Unglaub, Poussin and the Poetics of Painting: Pictorial Narrative and the Legacy of Tasso (Cambridge: Cambridge University Press, 2006).

40. Colantuono, Guido Reni's Abduction of Helen, 64.

41. Colantuono, "Lorenzo Lippi," 404. 
Farnese, demonstrates the lyrical embellishments for which Tasso would be criticized and, consequently, for which he would issue the Apologia of 1585. ${ }^{42}$ This unusual digression in subject has been related to the poet himself, inspiring artists approaches to appropriation of natural forms where all elements must be appended to the subject to ensure that the ideal is captured. The decree would be reiterated in the two Discorsi published in the last decade of his life. Aligning the goals of the poet and painter, who each must, above all, select and assemble disparate beauties, Tasso calls upon the Zeuxinian metaphor: "Still, by considering the good in various particular goodnesses, we form the idea of the good, just as Zeuxis formed the idea of the beautiful when he wished to paint Helen in Croton... And since I have to show the idea of the most excellent kind of poem, the heroic, I must not only offer one poem, even the most beautiful, as example, but, collecting the beauties and perfections of many, I must explain how the most perfect and most beautiful can be fashioned." 43 Thus elements from different genres must be considered, even for the ideal epic poem or painting. Published a year before the founding of their academy, the epic illustrating these assertions was well-known to the Carracci; however, knowledge of the later theoretical additions, begun as early as 1561, and how to apply them, were filtered through Bolognese literary academies.

As noted, these literary academies were more influential for the Carracci than their artistic counterparts, especially the Accademia dei Gelati. The academy was dedicated to the writing and criticism of love poetry, and the analysis of the lyrical works by Tasso. Though Tasso was himself not a member, a number of his close friends were, such as Cardinal Scipione Gonzaga (1542-1593), who he had traveled to Bologna in 1588, the year of the academy's founding. Although Quiviger has argued that Agostino's membership was limited, he would engrave the title page for the Recreationi published by the Gelati in 1590; around the same time, he would also paint a double-portrait of Zoppio and his wife. Given his membership, even if not able to participate fully, Agostino would have had access to first-rank members. Moreover, the literary academy can be tied more directly to the Carracci, for as Malvasia specifically notes the Aldrovandi, as well as Zoppio, founder of the Gelati, regularly attended the Carracci Academy. At such meetings, these men of letters would certainly have discussed the construction of poetic conceits and lectured on Tasso, while, Giordani points out, Gelati members even published poems dedicated to artists in their circle. For instance, in his Rime of 1615, Zoppio lauded a portrait painted by Albani and compared him to Apelles. ${ }^{44}$ The famed Bolognese poet Cesare Rinaldi (1559-1636) also praised a

42. Torquato Tasso, Apologia del S. Torquato Tasso in Difesa della sua Gierusalemme Liberata (Ferrara, 1585).

43. Tasso, Discourses on the Heroic Poem (trans.) Cavalchini and Samuel (Oxford: Clarendon Press, 1973), 6-7.

44. Melchiorre Zoppio, Rime dei Gelati, (Bologna, 1615), 54. 
portrait of a woman painted by the Agostino and included a sonnet entitled Pittura e posia suore e compagne. ${ }^{45}$ Also, Girolamo Giacobbi (1567-1629) edited an anthology of poems praising Guido Reni entitled Lodi al Signor Guido Reni raccolte dall'Imperfetto Accademico Confuso. ${ }^{46}$ With close ties to the Carracci Academy and Reni, Albani and Domenichino, Giacobbi was a member of the Accademia dei Gelati. Contributing to the anthology was none other than Malvasia, himself a member. ${ }^{47}$

Though the Carracci's membership with the Gelati has been debated, the relationship with poets in the academy is demonstrable. Roberto Zapperi, for instance, argues that Carracci involvement is related quite late in the preface of the history of the Accademia dei Gelati in1671 (published in 1672), listing Agostino as a member. Furthermore, only three painters are listed as active between 1588 and $1671 .{ }^{48}$ Perini counters that this should not be considered definitive since various members of the Gelati (Zoppio among them) were present as speakers at the Carracci Academy, documented by Benetto Morello in 1602 at Agostino's funeral (and reprinted by Malvasia and Bellori). ${ }^{49}$ In the same reference we find these poets named as official members of the Bolognese academy, and Agostino as a member of their literary academy..$^{50}$ Furthermore, Perini adds, Ludovico had extensive correspondence with literati; Albani was notably a great reader of poetry; Annibale cites Tasso by heart; Domenichino, who delights in music like Guido Reni, and was semi-illiterate still enjoys friendship with famed literary figures like Rinaldi. ${ }^{51}$ Along with first generation members of this organization, we find the famous poet, Cesare Rinaldi providing the lens through which the Carracci would view Tasso. Rinaldi was the Bolognese poet most closely associated with the fledgling art academy and was close friends with artists like Domenico degli Ambrogi (1600-1678), Gianluigi

45. Charles Dempsey, "Guido Reni in the Eyes of His Contemporaries," in Guido Reni, 1575-1642 (Los Angeles: Los Angeles County Museum of Art; Bologna: Nuova Alfa editoriale, 1988), 101-118.

46. Girolamo Giacobbi, Lodi Al Signor Guido Reni Raccolte dall'Imperfetto Accad. Conf. (Bologna: Nicolò Tebaldini, 1632).

47. Valerio Zani, Memoire, Imprese, e Ritratto de' Signori Accademici Gelati... (Bologna, 1672), 131-134.

48. Roberto Zapperi, Annibale Carracci: Ritratto di Artista da Giovane (Torino, 1989), 31.

49. Perini, “Ut Pictura Poesis: 1'Accademia dei Gelati e le Arti Figurative," 118.

50. Benedetto Morello, Il Funerale d'Agostino Carraccio Fatta in Bologna sua Patria da gl'Incamminati Accademici del Disegno (Bologna, 1603); Bellori, The Lives of the Modern Painters, Sculptors and Architects (trans.) Wohl, 126-133; Summerscale (Ed.), Malvasia's Life of the Carracci, 198-210.

51. "l'Albani gran lettore di poemi, Annibale che cita Tasso a memoria, Domenichino che si diletta di musica come il divino Guido che, pur semi-illetterato, gode dell'amicizia di letterati illustri quali il Rinaldi?" Perini, “Ut pictura poesis: 1'Accademia dei Gelati e le arti figurative," 115. 
Valesio (ca.1583-1633) and Ludovico Carracci. He was also very close to members of the Gelati, publishing his first volume of Tassian-inspired poetry the same year as the academy's founding. Influencing the next generation, Rinaldi and the Bolognese poets would even inspire Giambattista Marino prior to his visit in 1601-2. Therefore, even if the Carracci were unable to access the Discorsi at the time these were taking shape, Rinaldi and the Gelati would have been excellent resources.

More than acting as a cipher for Tassian poetics, the connections made through the Gelati would ensure the propagation of the Carracci's own precepts. While in Rome, Agostino and Annibale expanded their literary circle to include the cardinals Farnese and Aldobrandini, and the papal secretary Monsignor Battista Agucchi (1570-1632), who would write a programme for an Erminia and the Shepherds commissioned from Ludovico in 1602.52 The collaboration echoed a trend in the era whereby paintings would be based on instructions provided by rhetoricians or poets. ${ }^{53}$ Agucchi was Bolognese and could have known the Carracci from his time in Bologna; he was also a member of the Accademia dei Gelati and "participated in the obsession with Tasso's poetics that affected all of the members of that academy." ${ }^{54}$ Like his counterparts, he would be invested in integrating Tasso's approach to stylistic formation and integration into other art forms, namely the visual. In his overlooked Trattato della pittura of 1615, coauthored by the Carracci pupil Domenichino, we find the premise set forth that the model for eclectic appropriation adopted by poets is also applicable to the visual arts. Supporting his analogy, Agucchi cites Aristotle's Poetics:

Aristotle considered that one must necessarily agree that poetry imitates the quality of people as either better than he is in his own time, worse, or the same. This is proven with the example of painting since Polygnotus imitated that which was best, Pausias the worst, and Dionysius the same. And there is no doubt that among the ancients, many others did not use the styles themselves since Apelles, Zeuxises, Timaretes, Parrhasius, and several others imitated the best aspects of their subjects. ${ }^{55}$

52. Colantuono, Guido Reni's Abduction of Helen, 11; Clovis Whitfield, "A Programme for Erminia and the Shepherds by G.B. Agucchi," Storia dell' Arte 19 (1973): 223.

53. Colantuono, Guido Reni's Abduction of Helen, 11; Clare Robertson, "Annibale Caro as Iconographer," Journal of the Warburg and Courtauld Institutes 45 (1982): 160-181; Julian Kliemann, "Il Pensiero di Paolo Giovio nelle Pitture Eseguite sulle sue Invenzione," in Paolo Giovio (ed.), Il Rinascimento e la Memoria, atti del Convegno, Como 3-5 Giugno 1983 (Como: Società a Villa Gallia, 1985),197-223.

54. Colantuono, Guido Reni's Abduction of Helen, 174; Zani, Memoire, imprese e ritratti de'Signori Accademici Gelati..., 184-189.

55. "Considerando Aristotile, che necessariamente si dovevanodalla Poesia imitare persone di qualità, ò migliori di quelle del suo tempo, ò peggiori, ò simiglianti: lo provò con l'esempio della Pittura; perche Polignoto imitò i migliori, Pausone i peggiori, e Dionisio i simiglianti. E non è dubbio, che frà gli antiche, altri molti non usassero gli stili medesimi: poiche gli Apelli, i Zeusi, i Timanti, i Parrasii, \& altri diversi imitarono i 
The eclectic approach to the ennoblement of natural forms found resonance with both art forms. Tasso had already appropriated the Zeuxinian stratagem for selecting the best models in his Discorsi (1594), arguing that in order to conceptualize l'Idea del bello, the poet must take from the perfections of many different poems, as Zeuxis had many beautiful women. ${ }^{56}$ As he writes, "Among beautiful things let him choose the most beautiful, among great things the greatest, among marvels the most marvelous; and in the most marvelous let him still try to increase the novelty and grandeur." 57 Agucchi argued that Annibale had developed his late classical manner in a similar way, leading to his understanding of l'Idea della bellezza. ${ }^{58}$ The style and method of appropriation would become the model for artists of the next generation.

Perhaps more than any other, Nicolas Poussin is the seicentesque artist who most closely followed Agucchi's pronouncements and whose work most successfully embodied the adage ut pictura poesis. Early in his career, he would be introduced to these ideas by no less than court poet to Marie de'Medici, Giambattista Marino. The Neapolitan poet, Ackerman relates, had been Maggiordomo to Cardinal Aldobrandini at the same time as Agucchi, ensuring they would have had contact with similar interests. ${ }^{59}$ Like Agucchi, Malvasia records that Marino commissioned works from the Carracci, such as the Salmacis by Ludovico of 1607. ${ }^{60}$ Highly influenced by his predecessor Tasso, Marino's L'Adone of 1623 would further develop lyrical conceits to enliven his romantic digressions. Their connection went beyond professional admiration, though, for late in his life while living in Naples, Tasso had extended contact with the young poet and encouraged his talents. The significance of Tassian poetic strategies for pictorial narrative would be as important for Poussin as his mentor ${ }^{61}$ It is worth noting that of the significant contacts Poussin had throughout his life, only Marino is highlighted by all of his biographers, including Bellori, Passeri, and Félibien. Marino's three Sacred Discourses of 1614 set forth his art theoretical beliefs, though inconsistently. Ackerman noted that: "Marino is usually not very consistent in his philosophical borrowings; he was bored with the disciplined concepts of any system, and interested only in material for his flighty conceits." 62 In the second part of La Pittura, he elaborates on the theme of ut pictura poesis:

migliori." Agucchi, "Trattato della Pittura," in Denis Mahon, Studies in Seicento Art and Theory (Praeger, 1971), 256-257.

56. Tasso, Discorsi del Poema Eroico, 145.

57. Tasso, Discourses on the Heroic Poem (trans.) Cavalchini and Samuel, 53.

58. Mahon, Studies in Seicento Art and Theory, 250-252.

59. Gerald Ackerman, "Gian Battista Marino's Contribution to Seicento Art Theory," The Art Bulletin 43, no. 4 (1961), 327.

60. Summerscale (Ed.), Malvasia's Life of the Carracci, 310.

61. Unglaub, Poussin and the Poetics of Painting, 4.

62. Gerald Ackerman, "Gian Battista Marino's Contribution to Seicento Art Theory," The Art Bulletin 43, no. 4 (1961), 331. 
"Many are the relationships, and great are the analogies, as believe all the sages, between canvas and paper, between colors and ink, between brush and pen." 63 He delineates the art into two parts: Disegno and Colorito. He further divides Zuccaro's definition of Disegno into two parts roughly corresponding to the notions of disegno interno and esterno. He does introduce an original intercessor in Disegno practico, stating: "whose office is to put into operation conceits or seen objects, takes ordinarily three ways to work in earthly painters. One way is to make up the thing in one's mind, which is to say, doing it from practice, or indeed, from fantasy. The second is to discipline oneself exactly to the rules of perspective..." 64 The less abstract vocabulary is remade closer to the workshop tradition of the Renaissance and, importantly, comprehensible to non-specialists. Through his contact with his friend and mentor, Poussin would have developed an understanding of classical mimesis and appropriation. This is nowhere more evident than in the artist's own theoretical excurses, the twelve short paragraphs known as the Osservazioni, published at the end of his biography by Bellori. ${ }^{65}$ Significantly, the source most often excerpted for these aphorisms was Tasso's Discorsi.

The aphorisms in the Osservazioni sopra la Pittura, Bellori tells, were assembled for Poussin's own treatise on art in the 1640s. ${ }^{66}$ The short paragraphs are fashioned entirely of phrases and entire sentences taken verbatim from earlier authors without citations. While the notations seem random, Colantuono has pointed out that these were written in a particular aphoristic style that imitated that of Leonardo's Trattato della pittura, which were made up of short paragraphs that were also each separate and individually titled. ${ }^{67}$ Poussin, Unglaub points out, had access to his treatise as it was in the possession of his patron, Cassiano dal Pozzo, at the time being prepared for publication. ${ }^{68}$ As Colantuono and Unglaub have rightly surmised, the careful selections from Tasso were purposeful and deliberate. Poussin would truncate many definitions to make them universal principles, such as his Diffinizione della Pittura and Come l'arte avanzi la natura. When defining painting, Poussin selects the definition provided by Tasso, which stressed choosing the proper subject as the most important aspect of the field: "Painting is none other than the imitation of human actions,

63. Ackerman, "Gian Battista Marino's Contribution to Seicento Art Theory," 331.

64. Ackerman, 332.

65. Bellori, The Lives of the Modern Painters, Sculptors and Architects (trans.) Wohl, 338-339.

66. Blunt, "Poussin's Notes on Painting," Journal of the Warburg Institute 1, no. 4 (1938): 344-351.

67. Anthony Colantuono, "Poussin's Osservazioni Sopra la Pittura: Notes or Aphorisms?" Studi Secenteschi 16 (2000), 286.

68. Unglaub, Poussin and the Poetics of Tasso, 10. 
which properly constitute imitable actions." 69 Aligning the two disciplines goals, Poussin merely replaces poesia with pittura as he reiterates the definition of Tasso that would be followed by Bellori. Unglaub has related that by truncating Tasso, Poussin distills his idea to a universal principle..$^{70}$ These sentiments are echoed in the longest aphorism Della Idea della bellezza, where he expounds on the preparatory process necessary for artists to undertake in order to guarantee beauty in their works, similar to the recommendations Tasso sets forth for the heroic poet: "to choose matter fit to receive the most excellent form which the poet's art seeks to introduce into it."71 The process conforms both to the Zeuxinian model of Tasso, followed by the Carracci, as well as the definition of art and importance placed on the intellective faculty responsible for selecting the most beautiful, but also "good" forms. ${ }^{72}$ More important for the issue at hand, however, is not the alignment with Tassian poetics, but rather from where the excerpt derives.

Blunt first noted that the passage is lifted from the 1591 Italian translation of Albrecht Dürer's (1471-1528) treatise Della simmetria dei corpi humani libri Quattro by the astronomer Giovanni Paolo Gallucci. ${ }^{73}$ The treatise consists of the original four books published by Dürer along with an additional Preface, short biography of the artist, and Libro Quinto. While the Preface seeks to emphasize the affinities between painting and poetry, elaborating on how their goals are aligned in attempting to know the passions of the soul through evocative description, Poussin's excerpt derives from the last chapter in the final book where the translator's own original contribution can be found. Here Gallucci expands on Ficino's doctrine in the Convivio, reiterating:

What thing consists of the beauty of the body? A certain liveliness of action, and a certain grace, that shines in the same beautiful thing for the influence of its own idea. This splendor does not descend into matter if the material is not properly prepared...now this preparation of the body that lives consists in three things: order,

69. Bellori, The Lives of the Modern Painters, Sculptors and Architects (trans.) Wohl and Wohl, 478.

70. Unglaub, Poussin and the Poetics of Tasso, 14.

71. Bellori, Le Vite de Pittori, Scultori e Architetti Moderni, 461-462; Bellori, The Lives of the Modern Painters, Sculptors and Architects (trans.) Wohl and Wohl, 339.

72. Unglaub, Poussin and the Poetics of Tasso, 14.

73. Gallucci, Della Simmetria dei Corpi Humani, Libri Quattro; Anthony Blunt, Nicolas Poussin (London: Pallas Athene, 1967), 364. 
mode, and species; the significant order being the intervals of the parts, the quantity the mode, the species of lines, and colors. ${ }^{74}$

The citation here naturally admonishes those artists who do not seek to improve upon nature and the models that they use to represent their subjects. The preceding chapters clarify that one would begin with a live model, but filter the final appearance through descriptions of poets and an understanding of the epic and ideal. The practical application of these theoretical precepts was echoed by Poussin in another Observation entitled 'Of the Bounding of Lines of Drawing and Color. 'As he wrote, "A painting will appear elegant when its extreme elements join the nearest by means of indeterminate ones in such a fashion that they do not flow into one another too feebly nor yet with harshness of line and colors; and this leads one to speak of the harmony of discord of colors and of their bounding lines." ${ }^{75}$ Naturally, the artist would draw on this practical manual in order to articulate his own views.

In his selection of the final theoretical justification for the book, Poussin validates the usefulness of the preceding reference material for artists. In the previous 57 chapters, Gallucci outlines the range of temperaments, emotions and body types that artists must familiarize themselves with in order to master their craft. As a practical reference guide, we can imagine how this would supplement artists' educations. For instance, should Poussin receive a commission for a Tancred and Erminia (a popular subject in the Carracci circle), he could turn to the corresponding description of each character, supported by descriptions of the figures themselves by poets like Tasso. In the chapter On the Beauty of Human Bodies, Especially Women, Gallucci begins by stating, "Even though the painter is obliged to imitate nature, he, nevertheless, strains himself in attempting to surpass it by choosing only the most beautiful parts... The wise painter should make a diligent effort to understand and consider what is written about beauty here and then take into account the general consensus of his time." 76 The

74. "Che cosa è finalmente la bellezza del corpo? Una certa vivacita di attione, \& una certa gratia, che risplende nella istessa cosa bella per l'influsso della sua idea. Questo fulgore non descende in quello, fin che la materia non sia preparata più, che sia possibile, ora questa preparatione del corpo, che vive consiste in tre cose, nell'ordine, nel modo, \& nella specie, l'ordine significa l'intervalli delle parti, il modo la quantita, la specie le linee, \& i colori." Gallucci, Della Simmetria dei Corpi Humani Libri Quattro, 143

75. Determini del Disegno, e del Colore. Blunt, Nicholas Poussin, 362. "La pittura a sarà elegante quando gli ultimi termini con li primi per via delli mezzi, saranno cogiunti in maniera che non concorrino troppo fiaccamente, ò con asprezza di linee, e di colori, e qui si può parlare dell'amicita, e nimicitia de'colori, e de'loro termini." Bellori, Le Vite de Pittori, Scultori e Architetti Moderni, 460.

76. James Hutson, Gallucci's Commentary on Dürer's 'Four Books on Human Proportion': Renaissance Proportion Theory (Cambridge, UK: Open Book Publishers, 2020), 121-122. 
description is followed by examples provided from poets, ancient and modern. Following Petrarch, Aristotle and Homer, excerpts from Ariosto and Tasso provide a literary model for artists to follow. In describing the idea of beauty in the figure of Armida, Tasso writes:

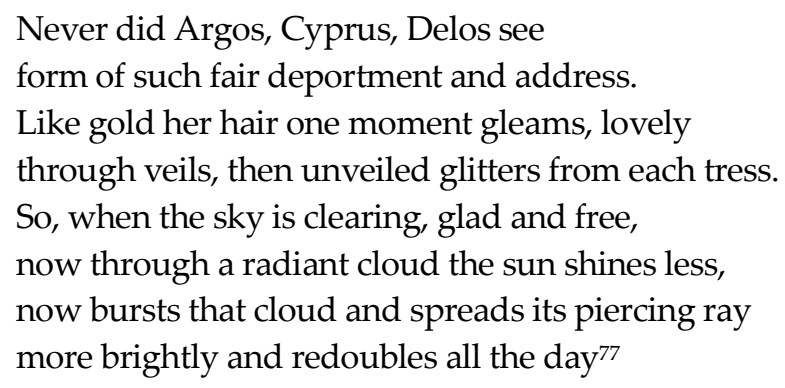

As per usual, following examples of each type of figure painters would be called upon to represent described by poets, Gallucci then directs the reader to the appropriate one of the Four Books where Dürer would outline the mathematical armature on which to hang the affetti. Each of the descriptions of the ten sets of proportions is accompanied with three woodcut illustrations representing the figures from the front, side, and back, along with the associated fixed measurements. Instructions on how to use the leading lines of perspective to find and apply the fixed points on a human model are then explained. Then, parts of the body are discussed with instructions on how to draw the desired subject, and, finally, each book ends with a table of the proportions. With the measurements provided by Dürer, Gallucci appends physiognomic studies along with quick axiomatic reference for appropriate musculature and complexion, as well as attitude, facial features, hair, beard, and eye color, and even facial lines. The artist would be reassured of the prescription's legitimacy as it was supported with the authority of poets and ancient authors (Tasso, for instance, is read alongside Homer, Virgil and Seneca).

The summary of classical sources in manuals, such as Gallucci's, also acted as a sort of crib notes that would assist artists in engaging scholars in conversations. This aids in explaining how, even without a rigorous classical education, so many of Poussin's biographers and patrons marveled at the extent of his literary knowledge early in his career right after moving to Rome. I should clarify here that I am not suggesting that artists (especially in the Carracci circle) did not read the epics of their day and engage directly with the vernacular material. On the contrary, there is little disagreement on the importance of the Tassian legacy for the artists discussed here; multiple sources corroborate the relationships and direct engagement with poetic material like his romantic epic. But where the

77. Torquato Tasso, The Liberation of Jerusalem (trans.) Max Wickert (Oxford: Oxford University Press, 2009), 4: 29-31; Hutson, Gallucci's Commentary on Dürer's 'Four Books on Human Proportion,' 124. 
major poetic trends of the day provided Carraccisti with a depth of knowledge, the lacking breadth, provided by a traditional classical education, had to be supplemented, especially with regards to the more obscure and ancient sources.

\section{Conclusion}

To conclude, I should like to reiterate my assertion that the relationship between artists and literati was more complex than the occasional collaboration or cribbed leitmotif; innovative pictorial methods were assembled from the various encounters between the two groups, as in the case of the Gelati and Carracci. Moving from illustrating individual scenes or passages in epics, like the Gerusalemme and l'Adone, Carraccesque artists internalized Tassian and Marinesque strategies of idealized imitation to apply on sundry projects unrelated to the original subject matter. The intertwining of poetic and artistic theory and historiography is demonstrable beyond their related goals: the narrative woven by biographers like Bellori reveals close associations between all three parties- artists, poets and academics, and biographers. Tasso would play a significant role in the nascent curriculum of the Carracci academy, inspiring not only illustrations of his literary epic, but their very working process; Marino would guide the young Poussin to do the same, encouraging his move to Rome with the poet; Bellori used the work of both Tasso and Marino as an inspiration for his theoretical-evaluative tool, the Idea, chronicled the importance of each to artists, and even wrote his own canzone in their modes. The result of the relationships fostered between these circles would be the creation of new rhetorical visual strategies, thus validating the oft-repeated Albertian appeal and Horatian adage: $u$ t pictura poesis. Through their close associations with poets and literary figures of their day, artists were able to shore up any deficiencies left from their unfinished earlier grammar school educations, while the understanding of how to apply these poetic strategies to the visual arts would be further reinforced through treatises and manuals of the day. The reality that comes into focus of early modern artists is neither one of an artist-philosopher nor workshop grunt, but instead a savvy practitioner navigating the shifting expectations of various groups required for their professional success.

\section{Bibliography}

Ackerman, Gerald. "Gian Battista Marino's Contribution to Seicento Art Theory." The Art Bulletin 43 no. 4 (1961): 326-336.

Bellori, Giovan Pietro. Le Vite de Pittori, Scultori e Architetti Moderni. [The Lives of Modern Painters, Sculptors and Architects.] Rome, 1672. Edited by Evelina Borea and Giovanni Previtali. Turin: Einaudi, 1976. 
Bellori, Giovan Pietro. The Lives of the Modern Painters, Sculptors and Architects. Translated by Helmut Wohl and Alice Sedgwick Wohl. New York: Cambridge University Press, 2005.

Blunt, Anthony. "Poussin's Notes on Painting." Journal of the Warburg Institute 1, no. 4 (1938): 344-351.

Blunt, Anthony. Nicolas Poussin. London: Pallas Athene, 1967.

Cavazzini, Cavazzini. Painting as Business in Early Seventeenth-Century Rome. University Park, Pennsylvania: The Pennsylvania State University Press, 2008.

Colantuono, Anthony. Guido Reni's Abduction of Helen: The Politics and Rhetoric of Painting in Seventeenth-Century Europe. Cambridge: Cambridge University Press, 1997.

Colantuono, Anthony. "Poussin's Osservazioni Sopra la Pittura: Notes or Aphorisms?" Studi Secenteschi 16 (2000).

Colantuono, Anthony. "Lorenzo Lippi, Torquato Tasso and Seventeenth-Century Pictorial Stylistics." In L'Arme e gli Amori. Ariosto, Tasso and Guarini in Late Renaissance Florence II, edited by M. Rossi and F. Gioffredi Superbi. Firenze: Olschki, 2004.

Colantuono, Anthony and Steven Ostrow (Eds). Critical Perspectives on Roman Baroque Sculpture. University Park, Pennsylvania: The Pennsylvania State University Press, 2014.

Dempsey, Charles. "Some Observations on the Education of Artists in Sixteenth-Century Florence and Bologna." Art Bulletin 62 (1980): 552-569.

Dempsey, Charles. "Guido Reni in the Eyes of his Contemporaries." In Guido Reni, 15751642. Los Angeles: Los Angeles County Museum of Art; Bologna: Nuova Alfa Editoriale, 1988: 101-118.

Edis-Barzman, Karen. The Florentine Academy and the Early Modern State: The Discipline of Disegno. Cambridge: Cambridge University Press, 2000.

Friedlaender, Walter. Mannerism and Anti-Mannerism in Italian Painting. New York, 1965.

Gallucci, Giovanni Paolo. Della Simmetria dei Corpi Humani, Libri Quattro. [On the Symmetry of the Human Bodies, Books Four.] Venice, 1591. Reprinted, Venice: Roberto Meietti, 1594.

Giacobbi, Girolamo. Lodi Al Signor Guido Reni raccolte dall'Imperfetto Accad. Conf. [Praises to Mr. Guido Reni collected by the Imperfect Accad. Conf.] Bologna: Nicolò Tebaldini, 1632.

Goldstein, Carl. Visual Fact over Verbal Fiction: A Study of the Carracci and the Criticism, Theory and Practice of Art in Renaissance and Baroque Italy. Cambridge, New York: Cambridge University Press, 1988.

Goldstein, Carl. Teaching Art: Academies and Schools from Vasari to Albers. New York, 1996.

Grayson, Cecil (Ed.) Leon Battista Alberti on Painting and Sculpture: The Latin Texts of 'De Pictura' and 'De Statua.' London: Phaidon Press, 1972.

Grendler, Paul. Schooling in Renaissance Italy; Literacy and Learning, 1300-1600. Baltimore: Johns Hopkins University Press, 1989.

Hutson, James. Gallucci's Commentary on Dürer's 'Four Books on Human Proportion': Renaissance Proportion Theory. Cambridge, UK: Open Book Publishers, 2020.

Kliemann, Julian. "Il Pensiero di Paolo Giovio nelle Pitture Eseguite sulle sue Invenzione." [The Thought of Paolo Giovio in the Paintings Made on his Inventions.] In Il Rinascimento e la memoria, atti del Convegno, Como 3-5 Giugno 1983, edited by Paolo Giovio, 197-223. Como: Società a Villa Gallia, 1985. 
Lukehart, Peter (Ed.) The Accademia Seminars: The Accademia di San Luca in Rome, c.15901635. CASAVA Seminar Papers 2. New Haven, London: National Gallery of Art Studies in the History of Art, 2009.

Mahon, Denis. Studies in Seicento Art and Theory. Praeger, 1971.

Malvasia, Carlo Cesare. Felsina Pittrice. Edited by Adriana Arfelli. Bologna, 1961.

Morello, Benedetto. Il Funerale d'Agostino Carraccio Fatta in Bologna sua Patria da gl'Incamminati Accademici del Disegno. [The Funeral of Agostino Carraccio Made in Bologna, his Homeland by the Accademici del Disegno.] Bologna, 1603.

Pade, Marianne. On Renaissance Academies: Proceedings of the International Conference "From the Roman Academy to the Danish Academy in Rome - Dall'Accademia Romana all'Accademia di Danimarca a Roma": The Danish Academy in Rome, 11-13 October 2006. Roma, 2011, 34-51.

Perini, Giovanna. “Ut Pictura Poesis: 1'Accademia dei Gelati e le Arti Figurative." [Ut Pictura Poesis: the Academy of Ice Cream and the Figurative Arts.] In Italian Academies of the Sixteenth Century, edited by D. S. Chambers and Francois Quiviger, 113-126. London: The Warburg Institute, 1995.

Pevsner, Nikolaus. Academies of Art, Past and Present. New York: De Capo Press, 1973.

Robertson, Clare. "Annibale Caro as Iconographer." Journal of the Warburg and Courtauld Institutes 45 (1982): 160-181.

Robertson, Clare. The Invention of Annibale Carracci. Silvana, 2008.

Summerscale, Anne (Ed.) Malvasia's Life of the Carracci. University Park, Pennsylvania: Pennsylvania State University Press, 2000.

Sutherland Harris, Anne. "Annibale's Legacy: Proposals for Giovanni Angelo Canini and Antonio Carracci." Master Drawings 43, no. 4 (2005): 440-456.

Tasso, Torquato. Apologia del S. Torquato Tasso in Difesa della sua Gierusalemme Liberata. [Apology of S. Torquato Tasso in Defense of his Liberated Jerusalem.] Ferrara, 1585.

Tasso, Torquato. Discourses on the Heroic Poem. Edited by Mariella Cavalchini and Irene Samuel. Oxford: Clarendon, 1973.

Tasso, Torquato. The Liberation of Jerusalem. Translated by Max Wickert. Oxford: Oxford University Press, 2009.

Unglaub, Jonathan. Poussin and the Poetics of Painting: Pictorial Narrative and the Legacy of Tasso. Cambridge: Cambridge University Press, 2006.

Vasari, Giorgio. Le Vite de' più Eccellenti Pittori Scultori e Architettori: Nelle Redazioni del 1550 e 1568. [The Lives of the Most Excellent Painters, Sculptors and Architects: In the Editorial Offices of 1550 and 1568.] Edited by Paola Barocchi. Firenze: Sansoni, 1966.

Whitfield, Clovis. "A Programme for Erminia and the Shepherds by G.B. Agucchi." Storia dell'Arte 19 (1973): 217-229.

Zani, Valerio. Memoire, Imprese, e Ritratto de' Signori Accademici Gelati... [Memoire, Imprese, and Portrait of the Gelati Academics...] Bologna, 1672.

Zapperi, Roberto. Annibale Carracci: Ritratto di Artista da Giovane. [Annibale Carracci: Portrait of a Young Artist.] Torino, 1989.

Zoppio, Melchiorre. Rime dei Gelati. Bologna, 1615. 